strated the untrustworthiness of any such differentiation of the anti-bodies as those contained in the euglobulin and those of the pseudoglobulin. No evidence has been adduced from our experiments to show that the agglutinins developed in the rabbit, goat and horse can be classed as belonging to either globulin, or that these anti-bodies can be separated from one another by ammonium sulphate fractioning of polyagglutinative sera.

\title{
I6 (159)
}

\section{Further observations of the effects of ions on the activity of enzymes.}

\section{By WILliaM N. BeRg and WILLIAM J. GIES.}

\section{[From the Laboratory of Biological Chemistry of Columbia Uni- versity, at the College of Physicians and Surgeons.]}

Previous communications from this laboratory ${ }^{1}$ have made it evident that peptolysis of fibrin is unequal in rate and extent in acid solutions of equipercentage, equinormal (isohydric), equimolecular, or equidissociated (isohydrionic) concentration. The same may be said of tryptolysis of the same protein in a series of bases of analogous concentrations.

We have found that the sequence of zymolysis, both in rate and extent in a given group of acid or basic solutions, varies considerably with the nature of the protein. This fact makes it impossible accurately to formulate statements regarding various phases of peptolysis or tryptolysis without specifying the particular protein involved in the process; it also renders doubtful various general conclusions of common acceptance pertaining to digestion that have been derived, in one research or another, from the use of a single protein. A study of the peptolysis of many proteins

1 Gies: American Journal of Physiology, 1903, viii (Proceedings of the American Physiological Society, 1902, p. xxxiv); the same journal, 1903, ix (Proceedings of the same Society, 1903, p. xvii); Gies and collaborators: Biochemical Researches, 1903, i, pp. 61-63. Also Berg (communicated by Gies): Science, 1906, xxiii, p. 335 (Proceedings of the Section of Biological Chemistry of the American Chemical Society in affiliation with Section C (Chemistry) of the American Association for the Advancement of Science, 1905); Proceedings of the American Association for the Advancement of Science, 1906, p. 33I. 
in a given series of acid solutions has therefore been undertaken, and an effort will be made to extend the observations to the tryptolysis of the same proteins in a given series of basic solutions.

The speed and extent of both peptolysis and tryptolysis are resultants of conflicting influences. In the case of peptolysis, for example, the hydrogen ions in a given acid solution are always essential and positive factors, whereas the accompanying anions or molecules or both appear to be, as a rule, non-essential and inhibitory factors. This conclusion is warranted by such results as the following, taken from our records of an experiment in which I gram quantities of fibrin were used in 100 c.c. portions of solution at $40^{\circ} \mathrm{C}$. :

\begin{tabular}{|c|c|c|c|c|c|c|c|c|c|}
\hline \multirow{4}{*}{$\begin{array}{l}\text { Acid solutions : } \\
m / 1 \mathrm{roHCl} \text { (c.c.) } \ldots \ldots \ldots \ldots \ldots \ldots \\
m / 1 \mathrm{LH}_{2} \mathrm{SO}_{4} \text { (c.c.) } \ldots \ldots \ldots \ldots \ldots \ldots\end{array}$} & \multicolumn{2}{|c|}{$\begin{array}{l}\text { A. Control solu- } \\
\text { tions (without } \\
\text { pepsin). }\end{array}$} & \multicolumn{7}{|c|}{$\begin{array}{l}\text { B. Digestive mixtures, containing equal } \\
\text { amounts of pepsin and } \mathrm{HCl}(m / 20) \text {, with } \\
\text { different proportions of } \mathrm{H}_{2} \mathrm{SO}_{4} \text {. }\end{array}$} \\
\hline & $a$ & $b$ & I & 2 & 3 & 4 & 5 & 6 & 7 \\
\hline & 100 & - & 50 & 50 & 50 & 50 & 50 & 50 & \\
\hline & & 100 & & 10 & 20 & $3^{\circ}$ & 40 & $5^{\circ}$ & 50 \\
\hline & & & 50 & 40 & 30 & 20 & I0 & & 50 \\
\hline & 100 & 100 & 100 & 100 & 100 & 100 & 100 & 100 & 100 \\
\hline & 960 & 994 & 162 & 439 & 430 & 500 & 553 & $5^{82}$ & 695 \\
\hline & 94 & 116 & 48 & 62 & 73 & 85 & 96 & 107 & 61 \\
\hline & & & & & & & $\mathrm{m} / 25$ & & \\
\hline
\end{tabular}

That acid molecules are not necessarily inhibitory in peptolysis is shown clearly by the appended results of an experiment similar to the one just referred to, but in which acetic acid was used instead of sulfuric acid. In the mixtures referred to below the dissociation of the acetic acid was slight and negligible :

\begin{tabular}{|c|c|c|c|c|c|c|c|c|c|}
\hline \multirow[b]{2}{*}{ Acid solutions : } & \multicolumn{2}{|c|}{$\begin{array}{l}\text { A. Control solu- } \\
\text { tions (without } \\
\text { pepsin). }\end{array}$} & \multicolumn{7}{|c|}{$\begin{array}{l}\text { B. Digestive mixtures, containing equal } \\
\text { amounts of pepsin and } \mathrm{HCl}(\mathrm{m} / 2 \mathrm{so}) \text { with } \\
\text { different proportions of } \mathrm{CH}_{3} \mathrm{COOH} \text {. }\end{array}$} \\
\hline & $a$ & $b$ & $\mathbf{I}$ & 2 & 3 & 4 & 5 & 6 & 7 \\
\hline$m /$ Io $\mathrm{HCl}$ (c.c.) ............. & 100 & - & 50 & 50 & 50 & 50 & 50 & 50 & \\
\hline$m / 10 \mathrm{CH}_{3} \mathrm{COOH}$ (c.c.) ....... & & 100 & & Io & 20 & 30 & 40 & 50 & 50 \\
\hline $\operatorname{ater}(c . c) \ldots \ldots \ldots$ & - & 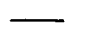 & 50 & 40 & 30 & 20 & 10 & $\Gamma$ & 50 \\
\hline Total volume...... (c.c.) ........... & 100 & 100 & 100 & 100 & 100 & 100 & 100 & 100 & 100 \\
\hline Weight of residue (mgs.) ) ${ }^{2} \ldots \ldots \ldots . .$. & 961 & $96 r$ & $\mathbf{r g 8}$ & r94 & 196 & 193 & 187 & I9r & 945 \\
\hline iram-atoms of $\mathrm{H}^{\bullet}$, per $\mathbf{1}, \infty 00$ liters. & - 94 & 1.3 & 48 & $4^{8}$ & 48 & 48 & $4^{8}$ & & 20.9 \\
\hline ncentration of $\mathrm{CH}_{3} \mathrm{COOH} . . . . .$. & & $m / 10$ & & & $\mathrm{~m} / \mathrm{s}^{\circ}$ & & & $2 / 20$ & $m / 20$ \\
\hline
\end{tabular}

1 Our data for neutralization precipitates (acidalbumin) and proteoses and peptones are omitted for brevity's sake. They accord with the data for undigested residues.

2 Our data for neutralization precipitates (acidalbumin) and proteoses and peptones are omitted for brevity's sake here also. They are in accord with the data for undigested residues.

${ }^{3}$ Although the $\mathrm{H}^{\bullet}$ concentration of an $m / 20$ acetic acid solution is approximately 
The results of this and similar experiments with acetic acid throw new light on the well known fact that peptolysis is almost negative in solutions of acetic acid alone. This lack of peptolytic efficiency on the part of acetic acid is apparently due to the low hydrion concentration of acetic acid solutions. The acetic acid molecules and anions, in the proportions above indicated, seem to be practically inert. It is obvious that peptolysis is neither favored nor interfered with materially by moderate amounts of acetic acid, a fact which suggests that the purely chemical phases of the normal gastric digestive process are practically unaffected by vinegar. Secretory conditions, however, are no doubt modified.

Experiments in this and other connections will shortly be completed before the detailed publication of our results.

0.9 gram-atom per $\mathrm{x}, 000$ liters, the dissociation of the same proportion of acetic acid in an $m / 20$ hydrochloric acid solution is reduced to 0.018 gram-atom per 1,000 liters. For this reason the $\mathrm{H}$ - concentration of the mixed acids is practically that of the hydrochloric acid $(m / 20)$ in each case. The dissociation of the hydrochloric acid was not materially affected by the acetic acid in the mixtures used. 